\title{
CONVERGÊNCIAS ENTRE MULHER-MARAVILHA E CONTO MARAVILHOSO
}

\author{
Convergences Between Wonder Woman And Wonder Tales
}

\author{
João Pedro Fernandes GOMES \\ Universidade Estadual Paulista \\ fernandesgomes.jp@gmail.com \\ Maria Celeste Tommasello RAMOS \\ Universidade Estadual Paulista \\ celeste.tommasello@gmail.com
}

\begin{abstract}
RESUMO: Apesar de parecerem distantes em sua concepção e características mais básicas, contos de fadas e superaventura podem ser considerados gêneros relacionados quando pensados dentro do grande gênero narrativo do maravilhoso identificado por Carolina Marinho. Este artigo explora alguns pontos de ligação entre ambos e busca demonstrar tal diálogo por uma análise do conto "A pequena sereia", de Hans Christian Andersen, em relação à história em quadrinhos Wonder Woman: Year One, roteirizada por Greg Rucka e ilustrada por Nicola Scott. A análise procura investigar se essas narrativas estão conectadas por uma relação de hipertextualidade e como se enquadram no maravilhoso, fazendo uso de formas específicas devido à diferença de recursos que possuem para contar histórias. PALAVRAS-CHAVE: Conto de fadas; A pequena sereia; Super-herói; Mulher-Maravilha; Ano Um.
\end{abstract}

\begin{abstract}
Even though they seem distant in their origins and characteristics, fairy tales and superhero stories can be considered related genres when they are examined through Carolina Marinho's perspective of the marvelous as a narrative genre. This paper explores some connections between both genres and demonstrates them through an analysis of "The Little Mermaid", by Hans Christian Andersen, in relation to the comic book Wonder Woman: Year One, written by Greg Rucka and illustrated by Nicola Scott. The analysis investigates if these narratives are linked by means of hypertextuality and how they fit into the marvelous genre in specific ways due to their different storytelling techniques. KEYWORDS: Fairy tale; The Little Mermaid; Superhero; Wonder Woman; Year One.
\end{abstract}




\section{INTRODUÇÃO}

Conto de fadas e superaventura não parecem ser, em uma investigação inicial, gêneros com muito em comum entre si. Afinal, é de se imaginar que exista um abismo entre eles pelos imaginários aos quais são comumente associados, um repleto de castelos, príncipes e princesas de tempos longínquos e outro de figuras mascaradas que entrecortam heroicamente os arranha-céus contemporâneos. Entretanto, uma visão mais panorâmica, que os considere como parte de uma linha progressiva das narrativas maravilhosas, permite perceber que não só há semelhanças entre as origens de ambos, que compartilham raízes nos mitos da Antiguidade, como também convergem em algumas características definidoras de seus respectivos gêneros.

Dentre os inúmeros super-heróis que habitam nossos tempos, talvez sejam poucos aqueles em que essa relação se demonstre de forma tão particular quanto em MulherMaravilha. Não só por suas origens estarem fundadas nos mitos greco-romanos, o que a aproxima das origens do próprio maravilhoso, mas por se utilizar narrativas canônicas dos contos de fadas que, ao serem retomadas, também imbuem características maravilhosas nesses quadrinhos.

Pretendemos, nas seções conseguintes deste estudo, demonstrar de que formas essa convergência se concretiza. Para tanto, inicialmente discutiremos a noção de maravilhoso como gênero narrativo elaborada por Carolina Marinho (2009), que sustenta uma ligação lógica entre narrativas aparentemente tão distantes. Em seguida, tais ligações serão exemplificadas nas páginas de Wonder Woman: Year One (no Brasil, Mulher-Maravilha: Ano $(\mathrm{m})$, história publicada mensalmente pela DC Comics em seis edições entre o final de 2016 e início de 2017, ano no qual foi reunida em um volume único. Pretendemos sugerir que, fazendo parte do mesmo percurso de evolução do maravilhoso, algumas características definidoras do gênero conto de fadas podem estar, também, presentes nos quadrinhos de super-heróis. Por fim, propomos um diálogo da HQ selecionada com o conto "A pequena sereia"(1837), de Hans Christian Andersen, com o qual possui similaridades significativas no modo como a estrutura básica do conto de fadas identificada por Vladimir Propp se manifesta.Nessa etapa, serão apresentadas considerações interartes, buscando as relações homológicas entre conto e história em quadrinhos, que os aproximam apesar de suas diferentes linguagens. 


\section{O MARAVILHOSO COMO GÊNERO NARRATIVO}

Os gêneros superaventura e conto de fadas ${ }^{1}$, como muitos outros ao longo da história, estão conectados se pensarmos no maravilhoso enquanto um grande gênero narrativo, unificado sob qualidades específicas que transcendem as formas literárias e artísticas. Quem propõe essa visão mais abrangente que as concepções comuns de maravilhoso é Carolina Marinho:

A ideia do maravilhoso na arte está tão vinculada às diferentes estéticas e, desse modo, não se confina a um momento singular da história nem a um campo específico, tendendo a um caráter diacrônico, na medida em que percorre o tempo histórico e, em certa medida, molda-se a ele, muito embora mantenha a unidade de suas características básicas, que se projetam à frente de qualquer limite temporal a que possa se submeter. $\mathbf{O}$ maravilhoso é transcendente e imanente, porque faz parte da própria natureza humana em sua essência e assim se torna também universal. (2009, p. 29, grifo nosso)

É notável, no decorrer da obra, a preocupação da autora em enxergar o maravilhoso como um elemento natural da experiência humana. Desde os primórdios, a humanidade o utiliza com propósitos diversos, seja o de explicar o funcionamento do mundo por narrativas divinas, instaurar medo como na Idade Média ou incitar a coragem em marinheiros para explorarem mares e terras desconhecidas com promessas de ouro e riquezas abundantes. Assumem, portanto, a forma de mitos, contos, pinturas e mesmo relatos de viagem, flertando com a dita factualidade da história.

Naturalmente, essas tantas manifestações apresentam mudanças relacionadas ao contexto sócio-histórico em que se inserem. É essa característica que permite que um percurso diacrônico seja traçado, como faz Marinho em seu trabalho. No contexto da contemporaneidade, no qual a autora decide atuar estudando o cinema de ficção científica, a forma predominante é a do que ela chama de maravilhoso cibernético. Ele está relacionado ao próprio início da era digital, e pode ser justamente definido como um maravilhoso:

produzido pelos meios digitais, tanto quando cria os jogos eletrônicos em formas narrativas, como também quando dá suporte para as narrativas cinematográficas trazendo temáticas estreitamente ligadas às possibilidades digitais. O filme Matrix [...] é um exemplo dessa modalidade de maravilhoso. (2006, p. 74) 
Contudo, o mundo da arte e do entretenimento contemporâneos, em toda sua multiplicidade, está longe de fornecer apenas o cinema como plataforma para disseminação do maravilhoso. A própria autora afirma isso ao questionar: "Poderíamos encontrar também uma narratividade em alguns jogos eletrônicos que se identificam com o maravilhoso? E quanto às histórias em quadrinhos dos super-heróis? Não haveria aí também um maravilhoso narrativo?" (2009, p. 175-176).

É especialmente em relação à última pergunta que inserimos nosso cenário de investigação. De que forma os quadrinhos de super-heróis manifestam seu aspecto maravilhoso? Não parece correto enquadrá-los no maravilhoso cibernético, já que as HQs são anteriores e independentes em relação aos recursos tecnológicos nos quais essa categoria se apoia. Em contrapartida, é inegável que a superaventura possua características que a associam ao grande gênero do maravilhoso, já que se enquadra na concepção de Marinho enquanto um

[...] efeito de linguagem vinculado ao fruir poético, conferindo às narrativas a mais pura liberdade e criando sua própria lógica a serviço do deleite imaginário e do prazer que o texto, tanto escrito quanto falado, ou mostrado em imagens, pode proporcionar àqueles que interagem com ele. O maravilhoso vai determinando uma estrutura narrativa peculiar, sedimentada na magia e em um mundo de ilusões que recorta a realidade, rearticulando-a de maneira singular. (2006, p. 18)

É fato que os quadrinhos manipulam a lógica para construir o universo dos superheróis, pautados numa versão da realidade que segue regras próprias. Mas as operações pelas quais isso ocorre se tornam mais difusas quando tomamos uma HQ como Wonder Woman: Year One, cuja análise será feita mais adiante. Ao mesmo tempo que possui os elementos clássicos da superaventura, como a história de origem, as habilidades sobrehumanas, o traje facilmente identificável e o senso de justiça (REBLIN, 2012) e segue a estrutura morfológica do conto maravilhoso apontada por Propp (GOMES, 2018), a HQ apresenta uma história imbuída de personagens da mitologia greco-romana e faz referências mais ou menos implícitas aos contos de fadas, ambas classificadas como narrativas maravilhosas.

Se, por um lado, isso torna a distinção genérica menos precisa, essa miscelânea intertextual pode ser vista como uma forma de destaque da presença do maravilhoso na superaventura. Isso porque, na história em quadrinhos selecionada, o maravilhoso não apenas se apresenta na estrutura morfológica proppiana ou pela manipulação da lógica a serviço do imaginário. Na verdade, a superaventura em quadrinhos, gênero intertextual 
por natureza, se utiliza da retomada de narrativas canonicamente pertencentes ao grande gênero do maravilhoso, fenômeno que pode ser lido como reafirmação de sua localização sob esse amplo guarda-chuva. Tal movimento é paralelo ao pensamento de Marinho, que considera a intertextualidade, apesar de não particular a ele, um dos traços mais relevantes da constituição do maravilhoso em uma narrativa: "Essa característica se fundamenta numa herança da oralidade, juntando fragmentos de textos em diferentes combinações permitindo, assim, que haja uma grande polifonia de vozes num imenso conjunto desse grande tecido narrativo" (MARINHO, 2009).

Essa hipótese alinha-se ao que Richard Reynolds considera um dos fundamentos do gênero dos super-heróis: "As histórias são míticas e usam ciência e magia indiscriminadamente para criar um senso de maravilhamento"2 (1992, p. 16, tradução nossa). Para o autor, a magia e a ciência coexistem nesse universo, o que simultaneamente afasta e aproxima a superaventura de categorias já existentes do maravilhoso, como o maravilhoso científico e o mito, colocando-a em posição distinta.

Poderia parecer exagerada a ideia de atribuir como uma das características principais da presença do maravilhoso nos quadrinhos a retomada de outros gêneros maravilhosos. Porém narrativas super-heroicas nasceram em berço intertextual. Evidência maior disso é o fato de Batman, Superman e Tocha Humana, personagens que dominaram a primeira grande onda de super-heróis das HQs, surgirem em revistas respectivamente intituladas Detective Comics, Action Comics e Marvel Mystery. Como aponta Henry Jenkins (2009), apesar de todos serem vistos como parte do gênero superaventura atualmente, seu surgimento foi incialmente compreendido em contextos diversos - policial, ação, mistério e assim por diante - que viriam a se mesclar no gênero do super-herói, que serve de ponto de confluência para toda essa diversidade. Por esse motivo, as fronteiras genéricas são mais facilmente transpostas na superaventura do que em qualquer outro gênero:

A crítica dos gêneros toma por garantido que a maioria das obras se
enquadram em um ou outro gênero, sendo a mistura de gêneros a
exceção, e não a norma. [...] Aqui [nos quadrinhos de super-heróis], a
diferença é sentida de forma muito mais poderosa dentro de um gênero
do que entre gêneros concorrentes, e a mistura de gêneros é a norma. O
gênero do super-herói parece capaz de absorver e remodelar todos os
outros gêneros.(JENKINS, 2009, p. 17-18, tradução nossa)

3 "Genre criticism takes for granted that most works fall within one and only one genre with genre mixing the exception rather than the norm. [...] Here [in superhero comics], difference is felt much more powerfully within a genre than between competing genres and genre mixing is the norm. The superhero genre seems capable of absorbing and reworking all other genres." 
Dadas tais particularidades, propomos iniciar a investigação a partir das características do conto de fadas enquanto gênero e averiguar como elas se manifestam nas narrativas super-heroicas. Afinal, se estão situados dentro do mesmo percurso de um gênero narrativo ao longo da história, é de se supor que superaventura e contos de fadas compartilhem entre si, de uma forma ou de outra, algumas convergências conceituais entre os princípios máximos que definem a cada um seu modo de contar histórias maravilhosas.

\section{DIÁLOGO ENTRE GÊNEROS}

Marinho (2009) sugere que a conexão entre os gêneros englobados no grande leque do maravilhoso se dá a nível estrutural, quando atende à morfologia do conto maravilhoso de Propp, e conceitual, no que se refere à maleabilidade da lógica a serviço da criação. Focalizaremos aqui o plano conceitual, buscando convergências específicas entre o conto de fadas e a superaventura em quadrinhos. Quais são as características mais fundamentais dos contos de fadas? Estariam elas ligadas à essência das narrativas super-heroicas? Tais questões são complexas e exigiriam esforços hercúleos para serem respondidas de forma satisfatória. Isso não impede, contudo, o traçar de algumas ponderações iniciais.

A começar pelo protagonista do conto de fadas, também chamado de herói ou heroína. Nelly Novaes Coelho acredita que ele possui uma jornada centrada na:

\footnotetext{
luta do eu, empenhado em sua realização interior profunda [...]. A efabulação básica do conto de fadas expressa os obstáculos ou provas que precisam ser vencidas, como um verdadeiro ritual iniciático, para que o herói alcance sua auto-realização existencial, seja pelo encontro de seu verdadeiro eu, seja pelo encontro da princesa, que encarna o ideala ser alcançado. (COELHO, 1987, p. 12-13, grifos da autora)
}

Em outras palavras, o protagonista do conto de fadas tem uma problemática motriz relacionada à realização pessoal, suprindo carências que dizem respeito às suas vontades, ambições e busca de preenchimento das lacunas interiores. É o caso da pequena sereia, cuja carência existencial se materializa no desejo de ser humana e possuir uma alma, como veremos mais adiante.

Esse caráter do protagonista dos contos parece diferir em muito do conceito de super-herói. Afinal, a motivação deste está diretamente relacionada ao sacrifício da esfera individual em favor da coletiva. Como definem Loeb e Morris, "Um super-herói é um indivíduo de força extraordinária, com pontos fracos e fortes, cujo nobre caráter o leva a fazer atos dignos. [...] destacam-se não só por causa de suas roupas e poderes, mas também 
por seu ativismo altruísta e a dedicação ao que é bom" (2005, p. 25-26). Haveria espaço em tal conceito para uma preocupação de nível existencial, que buscasse a satisfação profunda do eu?

Mark Waid, roteirista de algumas das mais reverenciadas histórias em quadrinhos tais quais Reino do amanhã (1996) e Superman: legado das estrelas (2003-2004), propõe que sim. Ao avaliar a figura do Superman, Waid acredita que é apenas abraçando sua verdadeira identidade e pondo em uso seus dons individuais a serviço dos outros é que o super-herói, assim como o ser humano, assume seu lugar justo na comunidade e se sente realizado:

Ao ajudar os outros, o Super-Homem ajuda a si mesmo. Quando ele vai ao socorro de alguém, está executando seus poderes distintos e cumprindo seu verdadeiro destino. E isso, claro, o beneficia. Quando ele assume sua história e sua natureza, lançando àquelas atividades que mais o satisfazem e confortam, ele ajuda os outros. Não existe uma escolha exclusiva entre as necessidades do indivíduo e as necessidades da comunidade maior. Não há uma contradição aqui entre o eu e a sociedade. Mas não deixa de ser paradoxal, embora inspirador. O SuperHomem cumpre seu destino e sua natureza; e o resultado é que muitas outras pessoas lucram com isso. (WAID, 2003, p. 21-22)

Dessa forma, o que o autor defende é que o Superman age em interesse próprio por meio da doação pessoal, e que a virtude altruísta também o beneficia individualmente. Parece justo associar, portanto, a figura do super-herói à do herói do conto de fadas como também interessada em uma espécie de realização pessoal, ainda que de forma indireta, já que é consequência do cumprimento de seu destino nobre ligado ao altruísmo. É só o colocando em prática que o super-herói consegue se sentir realizado e completar sua jornada.

Evidentemente essa realização individual do super-herói segue regras que divergem daquelas dos contos, pois estes seguem o que André Jolles (1976) caracteriza como uma moral ingênua. Segundo esse conceito, os contos não partem da premissa básica de que a virtude é recompensada e o vício é punido, como muito se difunde como parte do aspecto moralizante do gênero. $\mathrm{O}$ autor questiona o que fizeram Chapeuzinho Vermelho ou a Bela Adormecida de tão virtuoso, por exemplo, para que merecessem uma recompensa. Sugere que, na verdade, a justiça presente no conto é ingênua porque não se ampara na ética filosófica, mas, sim, em um julgamento emocional por parte do leitor. Enquanto leitores, desejamos que o protagonista do conto, que desde o início da narrativa é injustiçado por sofrimento, abandono, perdas materiais, pobreza, etc., tenha os danos 
e injustiças infligidas a ele reparados de forma grandiosa, e que os responsáveis pela dor sejam punidos severamente. Tanto castigo quanto recompensa são desproporcionais às virtudes e falhas das personagens em grande parte dos casos, e é daí que a satisfação narrativa é obtida: ela se orienta por nosso desejo passional de como as coisas deveriam acontecer em nosso mundo, onde nosso juízo sentimental não exerce poder algum.

Ao contrário do protagonista dos contos de fadas, os super-heróis, como definidos por Loeb e Morris, são seres de moral de fato elevada, que "buscam a justiça, defendendo os oprimidos, ajudando os indefesos e vencendo o mal com a força do bem" (2005, p. 24). Seus atos heroicos raramente são questionáveis, e quando cometem erros, há um limite que nunca é cruzado, de forma a manter sua moralidade intacta.

Nesse sentido, pareceria que Jolles e sua concepção de moral ingênua não se assemelham exatamente à moralidade nos quadrinhos de super-heróis, mais próximas do conceito filosófico de ética. Contudo, uma conexão pode ser observada pelo modo como a justiça e o controle do crime acontecem na superaventura:

Nos quadrinhos, a derrota do vilão toma o lugar da confissão do suspeito
ou a leitura do veredito como o momento de catarse, fornecendo tanto
a resolução quanto um senso de justiça, super-heróis frequentemente
parabenizando a si mesmos ou sendo parabenizados logo após pela
obtenção de "resultados". Nos quadrinhos, portanto, éa batalha final entre
o super-herói e o supervilão, o embate de Batman e Coringa no terraço,
o confronto entre Superman e Luthor no subsolo, que fornece algum
senso de conclusão narrativa [...]. A justiça é, assim, intervencionista,
e instituições legais enfraquecidas e, até certo porto, ignoradas; prisões
não podem conter o Luthor; psicólogos não podem curar o Coringa,
e Gordon se apoia no Batman (por isso o Bat-sinal). O super-herói se
torna o único repositório confiável de justiça. (BAINBRIDGE, 2009, p.
67, tradução nossa)

Em outros termos, é possível dizer que uma espécie de moral ingênua se faz presente, pois a derrota do vilão (predominantemente no formato de dominação física) é

\footnotetext{
4 "In comic books the defeat of the villain replaces the confession of the suspect or the delivery of the verdict as the moment of catharsis, providing both resolution and a sense of justice, superheroes often congratulating themselves or being congratulated afterwards for getting "results." In comic books, then, it is the final battle between superhero and supervillain, the rooftop struggle of Batman and the Joker, the underground confrontation between Superman and Luthor, which provides some sense of narrative closure [...]. Justice is therefore interventionist and legal institutions undermined and to some extent ignored; prisons cannot hold Luthor, psychologists cannot cure Joker, and Commissioner Gordon relies on Batman (hence the batsignal). The superhero becomes the only reliable repository of justice."
} 
o que dá a satisfação narrativa. Sua derrota é o momento de catarse, não a confissão do crime, a prisão pela polícia ou o julgamento, mesmo baseados numa sociedade organizada em sistemas oficiais de lei. Instituições legais dão lugar à justiça intervencionista dos super-heróis, o que causaria a desconfiança do leitor se não fosse a integridade de valores que o leitor a eles atribui. Em essência, é na batalha e derrota do vilão que a satisfação de cunho emocional do leitor de quadrinhos se concretiza, não tão diferente do que acontece na reparação de danos ao herói e punição intensiva do malfeitor dos contos de fadas.

É possível concluir, por essas características, que tanto vilões quanto superheróis extrapolam a esfera dos cidadãos comuns. Ambos são praticamente entidades que personificam o bem virtuoso e o mal a ser punido. E, por essa característica de oposição tão clara de valores, temos a última característica aqui abordada, mas de vital importância para os super-heróis e os contos de fadas: o maniqueísmo. Em outras palavras, "Não se conhece o meio termo, apenas os extremos: só há o feio (bruxa) e o bonito (princesa), o rico (rei) e o pobre (lenhador), o amor e o ódio, o bom e o mau" (VOLOBUEF, 1993, p. 102).

Passou-se a época em que super-heróis e seus supervilões eram o epítome da pureza de valores, cada vez mais sendo valorizada a complexidade de tais personagens. Umberto Eco justifica essa mudança como uma influência do romance:

A personagem mitológica da estória em quadrinhos encontra-se, pois, nesta singular situação: ela tem que ser um arquétipo, a soma de determinadas aspirações coletivas, e, portanto, deve, necessariamente, imobilizar-se numa fixidez emblemática que a torne facilmente reconhecível (e é o que acontece com a figura do Superman); mas, como é comerciada no âmbito de uma produção "romanesca" para um público que consome "romances", deve submeter-se àquele desenvolvimento característico, como vimos, da personagem do romance (ECO, 1979, p. 251).

Nem por isso os quadrinhos deixam de demarcar essa polarização no universo narrativo. Além do contraste ético, o maniqueísmo se observa até nas cores vestidas por cada um dos dois lados, que seguem clichês facilmente identificáveis. Perry Nodelman (1988) observou as cores relacionadas às esferas do bem e do mal em livros ilustrados ocidentais, afirmando que cores primárias geralmente se associam aos mocinhos e secundárias, em especial o roxo, o preto e o verde, são comuns aos vilões. O mesmo acontece nos quadrinhos, bastando uma página para evidenciar tal contraste. Notemos, na figura 1, que enquanto o vilão de Year One, Ares, traja um manto roxo e seus olhos 
brilham esverdeados nas sombras, a Mulher-Maravilha tem o uniforme com as três cores primárias, estando em destaque na imagem o amarelo dourado de seu laço mágico.

Figura 1: Capa de Wonder Woman \#12 (2016)

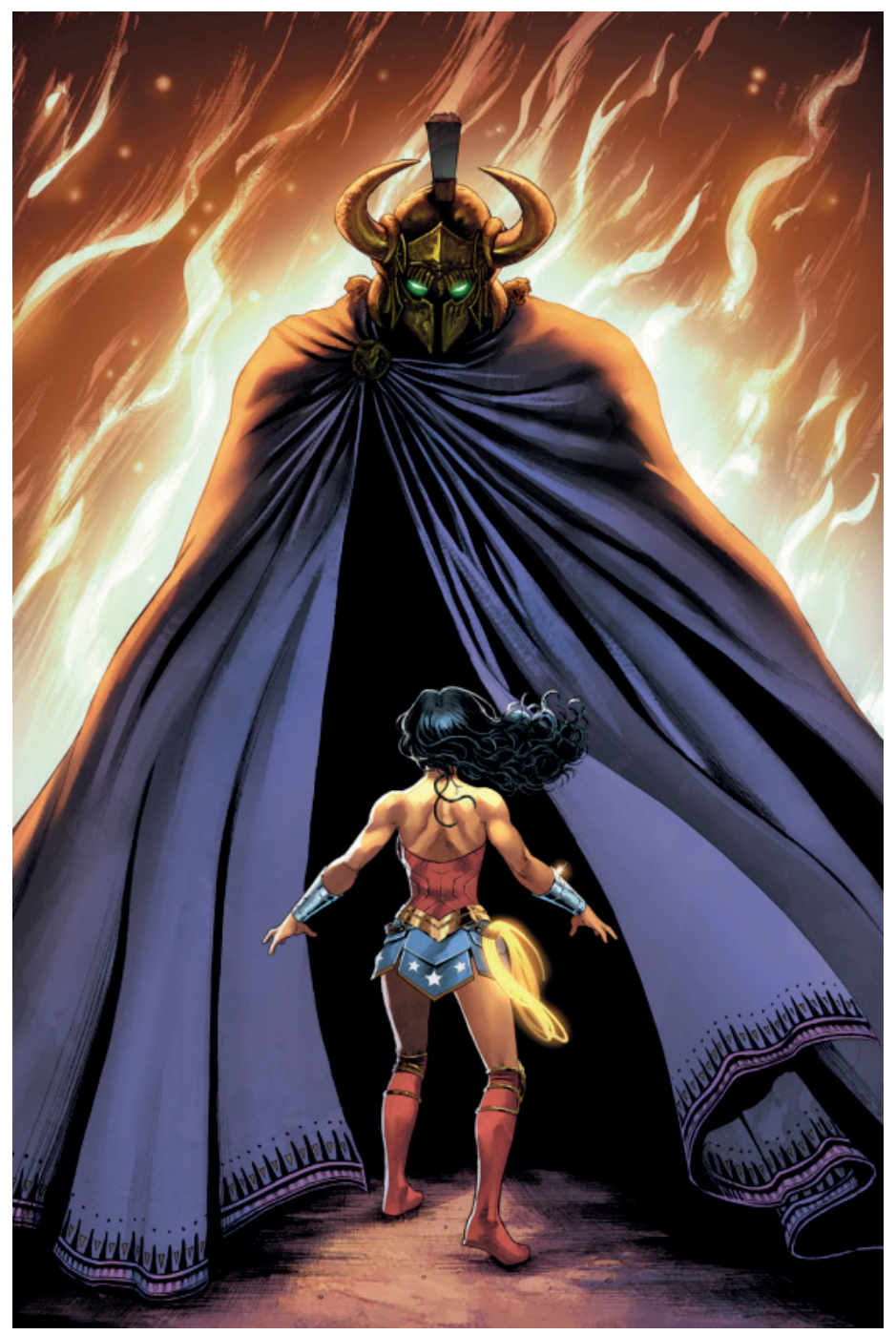

Fonte: RUCKA, G. et al. Wonder Woman: Year One. vol. 2. Burbank: DC Comics, 2017.

É claro que também existem divergências, por vezes gritantes, entre contos de fadas e super-heróis. Ao contrário da vagueza espacial nos contos, a superaventura geralmente se situa em cenários muito reconhecíveis, ou cidades fictícias como Gotham e Metrópolis, que aglutinam em si as características mais icônicas de grandes centros urbanos, tais quais o crime descontrolado e a evolução tecnológica. Da mesma forma, 
a imprecisão histórica do conto, que em parte justifica seu apelo a leitores de diversos séculos, dá lugar à obsessão dos quadrinhos estadunidenses com o hoje em sua forma mais urgente, acompanhando as mudanças sociais como poucas mídias conseguem. Há, ainda, a preferência pelo desenvolvimento da personagem. O super-herói tem nome público e identidade secreta, corpo dotado de superpoderes e fraquezas fatais, é questionado e se questiona, e sua filosofia é posta à prova pela aprovação pública. Distancia-se do protagonista do conto, da imaterialidade de seu corpo e da superficialidade de seus pensamentos (VOLOBUEF, 1993).

De toda forma, o foco proposto foi o de apontar intersecções que aproximam os dois gêneros como primos não tão distantes na família do maravilhoso. Como esses laços, até então estabelecidos no plano conceitual, podem se concretizar em duas formas de arte distintas - a literatura e a história em quadrinhos - é o que veremos a seguir.

\section{DIÁLOGOS ENTRE MULHER-MARAVILHA E "A PEQUENA SEREIA"}

A Mulher-Maravilha figura uma tradição de décadas de histórias, e não são poucas aquelas que ensejam comparações entre a protagonista, uma super-heroína, e personagens populares de contos de fadas. Em uma das narrativas, foi até mesmo confundida com a princesa Branca de Neve pela Rainha das Fábulas, vilã que incorpora o arquétipo de bruxa ou madrasta movida por ódio e inveja da donzela, tão característico dos contos. $\mathrm{Na}$ história, Diana cai em sono profundo após furar-se com um espinho e é acordada pelo beijo de um príncipe (WAID et al., 2014), num claro jogo paródico do que constitui um conto de fadas para o senso comum.

Mas indo além das referências mais claras em seu histórico de publicação, talvez não haja conto em memória recente que tenha influenciado a Mulher-Maravilha mais do que "A pequena sereia", do dinamarquês Hans Christian Andersen (1805-1875). Mesmo Allan Heinberg, roteirista de quadrinhos e, mais recentemente, da recente adaptação fílmica Mulher-Maravilha que estreou em 2017, admite tal inspiração: “A história como a vejo é A pequena sereia, especificamente a versão da Disney [...] Trata-se de uma mulher que foi criada em uma vida muito protegida e resguardada, que é curiosa a respeito de como a vida é lá fora e que quer ter suas próprias experiências. Ela quer estar onde as pessoas estão"5 (HEINBERG, 2017, tradução nossa).

\footnotetext{
5 "The story as I see it is The Little Mermaid, specifically Disney's incarnation [...] This is a woman who has been raised in a very protective, sheltered life, she's curious about what life is like outside and she wants to have her own experience. She wants to be where the people are"
} 
Apesar de Heinberg especificar que é a versão da Disney a responsável por suas ponderações, os elementos citados pelo roteirista remontam também às origens da Mulher-Maravilha nas HQs, que desde sua primeira aparição, em 1941, é mostrada como filha das amazonas, guerreiras mitológicas que se isolaram do chamado mundo dos homens até que a queda de um piloto de avião na ilha faz com que tais barreiras sejam revistas. Mais recentemente, a fase de Greg Rucka e Nicola Scott, responsáveis, respectivamente, pelo roteiro e arte de Wonder Woman: Year One (2016-2017), explora de forma ainda mais integral a ânsia de Diana em conhecer o mundo exterior à ilha, que dela exigiria sacrifícios tão grandiosos quanto os da pequena sereia ao ceder sua voz em troca de pernas. Acreditamos que indícios como esses são suficientes para afirmar com alguma segurança que, de forma consciente ou não, as pontes entre Mulher-Maravilha e "A pequena sereia" foram estabelecidas muito antes das palavras de Heinberg, em 2017, ou da adaptação da Disney, de 1989, virem a existir.

Uma leitura prévia revelou que algumas das funções universais do conto maravilhoso, como nomeadas por Propp, têm forte semelhança em sua manifestação nas histórias de "A pequena sereia" e Year One. Tal similaridade, juntamente com o fato de o surgimento do super-herói ter sido atrelado a outros gêneros, levou-nos à hipótese de que é possível que o conto esteja presente na HQ de forma classificável. Pela natureza mais ampla das referências, que retomam passagens específicas da história sem menção direta ao conto, acreditamos que ela se dê pelo mecanismo da hipertextualidade.

Tiphaine Samoyault, ao retomar Genette, criador do conceito, a define como uma forma de presença de um texto no outro que opera de forma vertical, sendo um hipertexto derivado de um hipotexto: "a hipertextualidade segundo Gérard Genette, oferece a possibilidade de percorrer a história da literatura (como das outras artes) compreendendo um de seus maiores traços: ela se faz por imitação e transformação" (SAMOYAULT, 2008, p. 32-33).

Com essa premissa em mente, averiguaremos alguns pontos de intersecção entre o conto e os quadrinhos. A análise buscará verificar de que maneiras duas representações artísticas diferentes podem dialogar entre si ao utilizarem recursos distintos na expressão de situações semelhantes, situações estas que integram a morfologia do conto maravilhoso elaborada por Propp e retomada por Marinho. Esse exercício permite observar se existem, efetivamente, convergências entre "A pequena sereia" e os quadrinhos da MulherMaravilha.

Uma primeira convergência entre as obras se encontra no que Coelho (1987) definiu como motriz dos contos de fadas, a busca existencial do herói ou heroína, função a 
(carência: "falta alguma coisa a um membro da família, ele deseja obter algo") na divisão de Propp (2010, p. 35). A jovem sereia tem uma grande ânsia de viver como os humanos e, assim, possuir uma alma. Tal carência é demonstrada de forma quase hiperbólica na narrativa:

\begin{abstract}
Nenhuma das sereias era mais curiosa que a caçula, e era também ela, tão quieta e pensativa, a que tinha de suportar a mais longa espera. Em muitas noites ela se postava junto à janela aberta e fitava através das águas azul-escuras,onde peixes espadanavam a água com suas nadadeiras e caudas. Podia ver a lua e as estrelas, embora sua luz fosse muito pálida. Através da água, pareciam muito maiores que aos nossos olhos. Se uma nuvem escura passava acima dela, sabia que era ou uma baleia que nadava sobre a sua cabeça ou um navio cheio de passageiros. Aquelas pessoas nem sonhavam que sob eles havia uma linda pequena sereia, estendendo os braços brancos para a quilha do barco. (ANDERSEN, 2010, p. 213-214, grifos nossos)
\end{abstract}

A carência da sereia se manifesta de forma saliente, não só sugerida pelo uso de adjetivos como curiosa, quieta e pensativa, mas, principalmente, pelo seu gestual tão simbólico de estender os braços em direção ao que acreditava ser o barco, espécie de pedido de socorro calado. Também é muito difundida a associação simbólica da cor azul às sensações de tristeza ou solidão devido à sua relação na natureza com o vazio do ar e da água. Adentrar o azul representa a entrada em um novo mundo, um mundo de divagações (CHEVALIER et al., 2006). O azul escuro do mar coincide, àquela hora, com o ápice do sofrimento da sereia, e empalidece a luz da lua e das estrelas, traços do mundo da superfície, do céu inalcançável e da noção de vida pós-morte pela ascensão divina. Em cenário tão obscuro, em que qualquer sombra, seja barco ou baleia, é alvo do clamor da jovem, ela se atém à esperança por seu gesto silencioso.

De forma tão demarcada quanto a carência da sereia é retratada a vontade de Diana de conhecer o que há além do horizonte visto do topo de Themyscira. Os primeiros momentos de Year One (Fig. 1) deixam claro que, assim como para a sereia, a comunidade em que vive, por mais encantadora que seja, não é o bastante para a amazona.

Apesar de se encontrar numa ilha, o que faz seu olhar esperançoso se dirigir ao horizonte, e não aos céus, o movimento das personagens (ambas princesas, é válido notar) é o mesmo. Mas nos quadrinhos, por sua natureza múltipla formada da união entre palavra, imagem e sequência, as informações a respeito de sua carência se manifestam por outros recursos.

Assim como no conto de Andersen, o azul é símbolo do estado de espírito da 
personagem. Mas em vez do azul escuro do mar, que na figura é quase cinzento, o objeto da página em que predomina o uso da cor é o manto de Diana. Para Chevalier et al. (2006), o azul é, entre muitos sentidos, distinto como a cor mais profunda, da imensidão, da divagação, da tranquilidade que se mescla à melancolia. A personalidade de Diana não poderia ser melhor descrita em tal cena, já que a amazona não se contenta dentro dos limites que possui e viaja o horizonte metaforicamente em busca de algo que existe além. Em crianças, o azul e o branco denotam também a falta de maturidade. Enquanto princesa e a mais jovem do local, assim como a pequena sereia é em sua família, a inexperiência não impede Diana de desejar o "além" que desconhece, tão misterioso quanto o mundo dos humanos é para a sereia. Ambas são imaturas, portanto, no sentido em que estão dispostas a lançar-se ao desconhecido sem cogitar as consequências negativas, capricho típico da juventude.

Figura 2: A carência de Diana

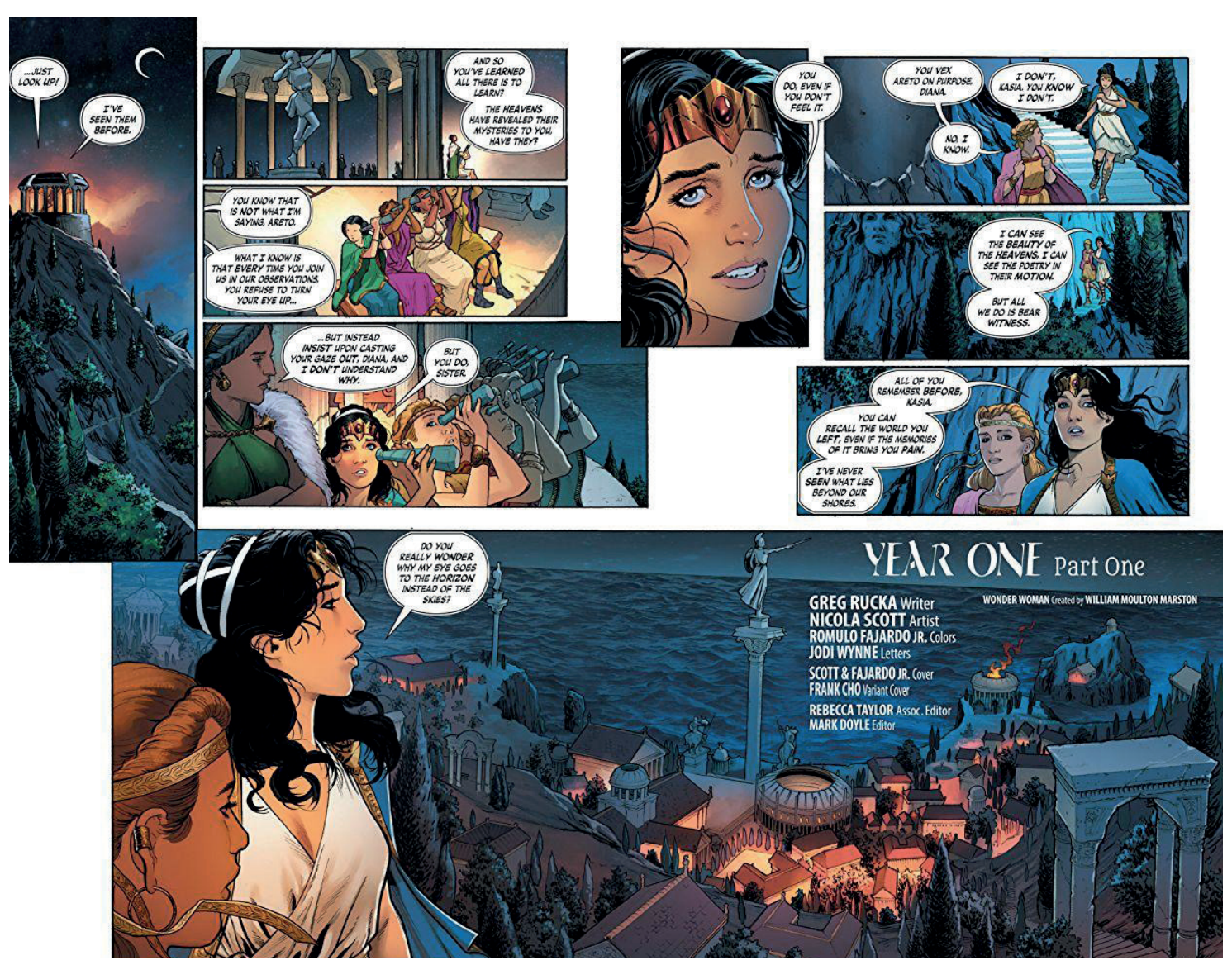

Fonte: RUCKA, G. et al. Wonder Woman: Year One. vol. 2. Burbank: DC Comics, 2017. 
Sabemos, assim, que ambas as personagens estão destinadas a, de fato, alcançar o mundo com o qual tanto sonham. Nos termos de Propp (2010), esse sonhar pode ser considerado uma motivação dentro das narrativas. A motivação serve como elemento essencial de ligação das partes do conto, pois justifica algumas ações das personagens, movimentando-o. No caso de motivações relacionadas à carência, como é o caso de nossas protagonistas,

A tomada de consciência daquilo que falta pode-se produzir do seguinte modo: o objeto que falta dá, involuntariamente, sinal de sua existência, mostrando-se por um instante, deixando atrás de si um rastro brilhante, ou aparece ao herói em alguma representação (narração, retrato). $\mathrm{O}$ herói (ou quem envia) perde seu equilíbrio mental, definha de saudade pela beleza que apenas entrevira uma vez, e a partir daí se desenvolve toda ação. [...] Quando se trata de uma princesa este elemento pode ter outros matizes. Podemos incluir nesta categoria os casos em que o herói vê, numa cafua proibida, o retrato de uma jovem extraordinariamente bela e por ela se apaixona perdidamente etc. (PROPP, 2010, p. 74)

A sereia almeja um mundo que conhece à distância, por observação platônica que alimenta ao cultuar objetos de seu jardim: "não admitia nada além de flores rosaavermelhadas que eram como o sol lá no alto, e uma bela estátua de mármore [...] de um bonito menino [...]" (ANDERSEN, 2010, p. 212). A amazona, por sua vez, deseja ampliar seus horizontes e explorar o mundo desconhecido, mesmo que ele não seja perfeito como o paraíso em que vive. E ambos os desejos se relacionam com a figura de uma espécie de príncipe, que motiva, de formas distintas, a partida da heroína.

Como mostra a canônica narrativa de Andersen, a motivação da sereia é também alimentada por sua paixão por um humano, explícita no trecho abaixo:

Por um instante houve alegria em seu coração, pois ela sabia que ninguém tinha uma voz mais bela que a sua em terra ou no mar. Mas em seguida seus pensamentos se voltaram para o mundo acima dela. Não conseguia esquecer o belo príncipe e a grande dor de não ter a alma imortal que ele possuía. Assim, saiu furtivamente do palácio do pai, e enquanto todos lá dentro cantavam e se divertiam, foi se sentar em seu jardinzinho, desolada. [...] De repente ouviu o som de uma buzina ecoando através da água, e pensou: "Ah, lá vai ele, navegando lá em cima - ele que eu amo mais que a meu pai ou a minha mãe, ele que está sempre em meus pensamentos e em cujas mãos eu depositaria alegremente minha felicidade. [...]" (ANDERSEN, 2010, p. 228-229, grifos nossos) 
É ingênua a relação, no conto, que a sereia estabelece com o príncipe. Mesmo que também tenha relação com o fato de ser o único humano com quem teve contato, tendo lhe salvado do naufrágio, seu amor por ele, maior do que pela própria família, é construído sem interação verbal alguma, apenas admiração à distância e semelhança do príncipe com a estátua de seu jardim. Está próxima à paixão instantânea descrita por Propp na citação acima, característica comum de muitos contos que se tornou um clichê do gênero, parodiado incessantemente por obras contemporâneas. Talvez não coincidentemente, o mesmo amor à primeira vista acontece na primeira história publicada da Mulher-Maravilha, em All-Star Comics \#8, de 1941. Steve Trevor, o piloto que cai com seu avião em Themyscira, é resgatado por Diana, que se apaixona por ele após salválo e cuidar de seus ferimentos enquanto está desacordado.

Já em 2016, Year One propõe uma nova perspectiva de contagem desse ponto da narrativa, mantendo seus elementos básicos (como a espécie de empatia da princesa pelo príncipe antes de qualquer diálogo) e utilizando recursos específicos das HQs para atualizar tal fórmula narrativa em direção a noções atualmente mais aceitáveis do ato de se apaixonar.

Investiguemos a imagem da Figura 3, que apresenta simultaneamente três facetas fundamentais dessa história da Mulher-Maravilha similares a momentos de "A pequena sereia". São eles a relação com o "príncipe", a caracterização da vida na ilha e o isolamento da princesa de sua família, acentuado durante uma festividade. 
Figura 3: Distanciamento da família e aproximação com o humano
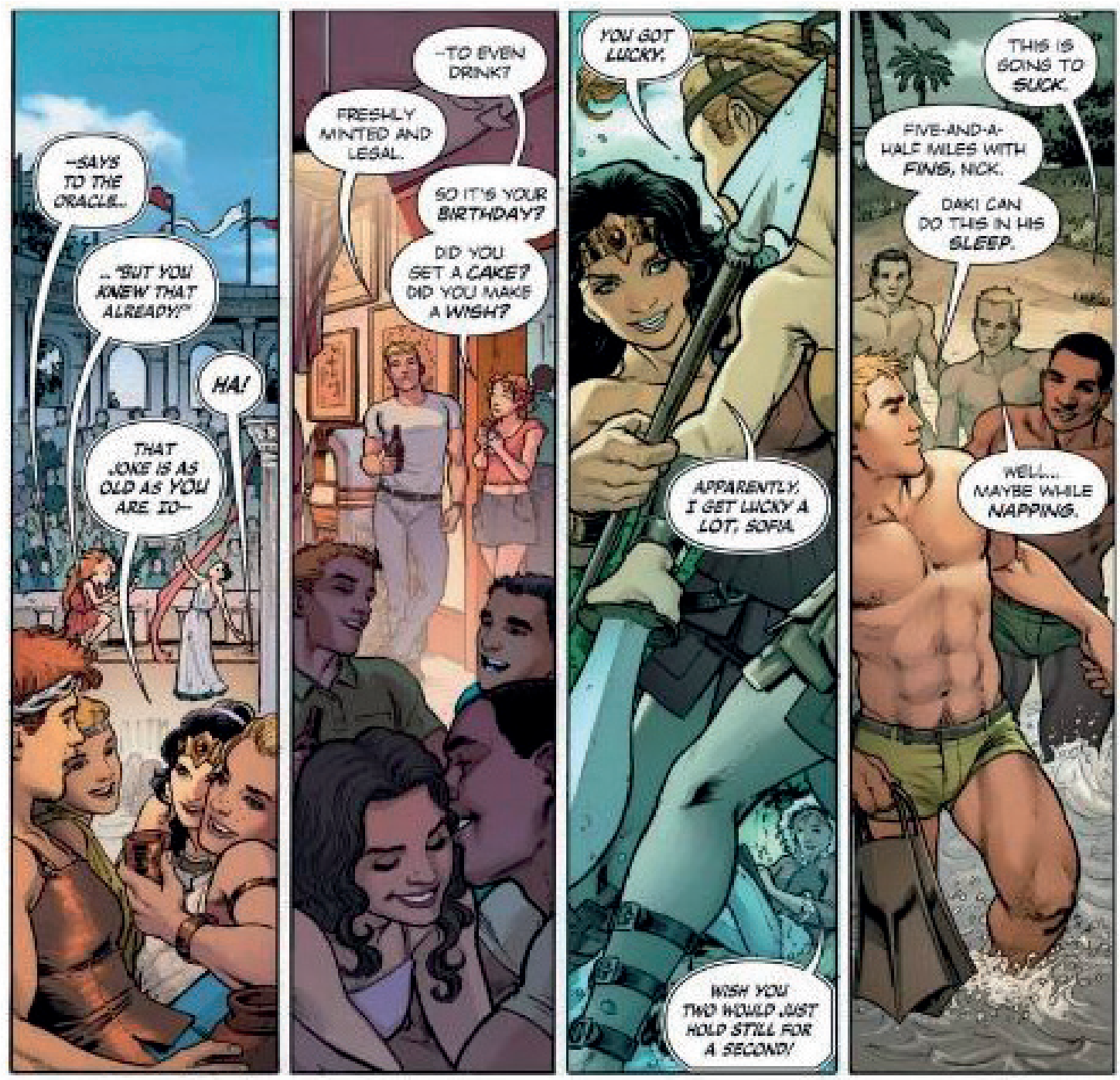

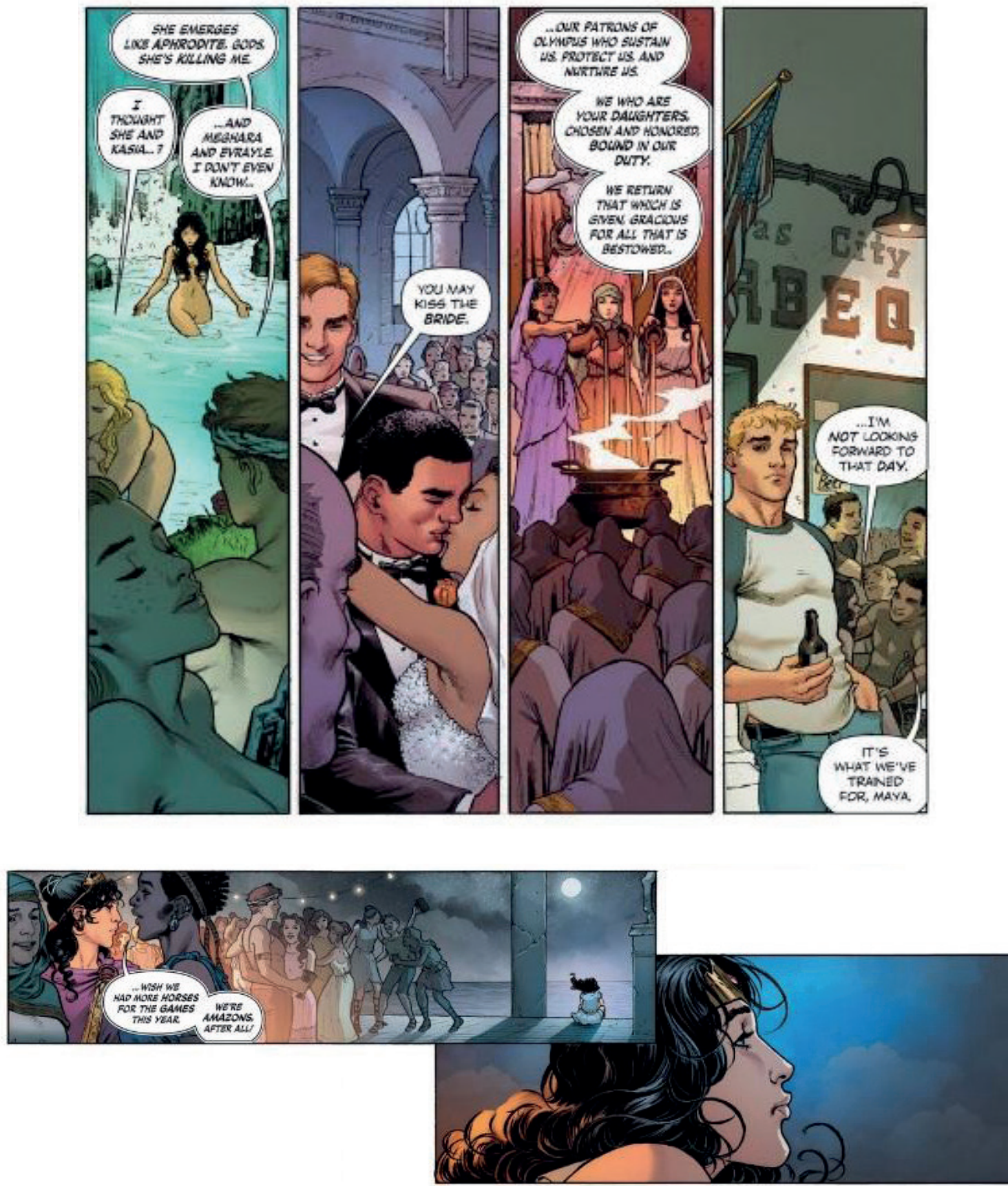

Fonte: RUCKA, G. et al. Wonder Woman: Year One. vol. 2. Burbank: DC Comics, 2017.

No conjunto superior de quadros, vemos cenas intercaladas da vida de Diana e Steve muito antes de ambos se conhecerem. Numa rápida categorização, é possível perceber que as duas primeiras cenas demonstram atividades de entretenimento, seguindo para momentos de treinamento para combate, ritos de amor e religião, e assim por diante. 
Tudo é feito em transições sutis entre um quadro e outro, fazendo parecer que, apesar da distância e de virem de mundos diferentes, a amazona e o soldado têm muito em comum. Isso os aproxima de forma profunda (ao contrário do que ocorre com a admiração da sereia pelo príncipe), e torna sua identificação inicial uma mera culminação da afinidade que já possuem sem saber.

Tal premissa é reforçada pelos dois painéis horizontais na parte inferior: o central, demonstrando a festividade das amazonas em preparação para seu torneio, e o posicionado no canto inferior direito da página. Se fosse traçada uma linha vertical no centro da figura, representando a divisão física da encadernação dos quadrinhos que divide a imagem em duas páginas, teríamos um cenário interessante. A parte superior, com oito quadros simétricos verticalmente, representaria o equilíbrio e estabilidade na relação entre Diana e Steve, e da amazona com a vida humana por consequência. Já na parte inferior, a divisão separaria o quadro horizontal central entre as amazonas se divertindo, coloridas em tons quentes, e Diana, à direita, em tons frios, isolada entre pilastras e iluminada apenas pelas cores frias da lua enevoada. Ao contrário da parte superior da página, a inferior não é simétrica verticalmente, e o quadro com Diana sozinha não só demonstra a perturbação e falta de equilíbrio entre ela e suas irmãs como também seu afastamento físico de todas elas, concretizado pela dobra da encadernação do livro.

Vê-se, nessa página, uma evidência das diferenças mais básicas entre as formas pelas quais quadrinhos e literatura constroem sentido. As mesmas ideias que levam muitas páginas e seleção de palavras cautelosa no conto aparecem de forma simultânea, e nem por isso desordenada, na própria mise en page $e^{6}$ de Year One. Da mesma forma, a diferença se replica na relação da sereia e da amazona com seus respectivos príncipes. Enquanto no conto há a clássica relação de amor à primeira vista, é possível ler a relação de Steve como sendo o "objeto" que falta dando sinal de sua existência para Diana. Este objeto seria o "mundo dos homens", que ela tanto anseia em conhecer, e do qual Steve é um fragmento. O fascínio da princesa, a princípio, não é romântico, mas, sim, de curiosidade pela raça que vive além da ilha e o quão semelhante ela é das próprias amazonas: “...ele sabia, mãe, ele sabia que os outros [soldados] haviam morrido. Ele chorou por eles como nós teríamos chorado por uma das nossas. Eu acho que ele os amava. [...] Isso não é tão

\footnotetext{
6 "The layout of the entire page, the way the panels relate to each other and the way they are arranged, is called 'mise en page' in comics" (KUKKONEN, 2013, p. 19). Tradução nossa: "A configuração de toda a página, o modo como os quadros se relacionam uns com os outros e o modo que são organizados é chamado 'mise em page' nos quadrinhos".
} 
diferente de nós, não é?” (RUCKA et al., 2017, n.p., tradução nossa)."

Outro momento em que a página fala por si em sua disposição de quadros, personagens e expressão, último caso que analisaremos aqui, é o da persuasão, que se aproxima da proibição (função $\gamma$ ) em termos proppianos. Neste trecho da narrativa, a mãe de Diana tenta convencê-la a não participar do torneio para escolher a melhor dentre todas as amazonas, que receberá a missão de devolver o soldado Steve Trevor ao chamado "mundo dos homens". Uma cena de persuasão semelhante também está presente em "A pequena sereia", porém na figura de outro membro da família, a avó:

"Por que não podemos ter uma alma imortal?" a Pequena Sereia perguntou, pesarosa. "Eu daria de boa vontade todos os trezentos anos que tenho para viver se pudesse me tornar um ser humano por um só dia e partilhar daquele mundo celestial." "Você não deveria se apoquentar com isso", disse a avó. "Somos muito mais felizes e vivemos melhor aqui do que os seres humanos lá em cima. [...] Sua cauda de peixe, que achamos tão bonita, parece repulsiva à gente da terra.

\section{A Pequena Sereia deu um suspiro e olhou pesarosamente para sua cauda de peixe.}

"Devemos ficar satisfeitos com o que temos", disse a velha senhora. "Vamos dançar e nos alegrar pelos trezentos anos que temos para viver - é bastante tempo, não é? Depois da morte, poderemos descansar e pôr o sono em dia"(ANDERSEN, 2010, p. 226-228, grifos nossos)

O diálogo salienta a imaturidade da jovem em relação à sua avó, que profere uma espécie de lição de moral, tão comum ao conto de fadas. Apesar de não haver uma ordem expressa, a hierarquia entre as duas, e o fato de a voz da razão repousar na mais velha, se torna evidente, reforçando o teor moral desse gênero literário. Como sabemos, a sereia não obedece tais conselhos e persiste em seu desejo. Sendo o desvio do final feliz e a inserção das dores e violências do mundo moderno uma característica fundamental dos contos de Hans Christian Andersen (GONGORA; MARTHA, 2009), não é de se surpreender que as atitudes da sereia tenham como desfecho inúmeras dores metafóricas e literais, bem como a frustração amorosa e, ao final, a sua morte.

\footnotetext{
7 " ...he knew, mother, he knew the others had died. He wept for them as we would one o four own. I think he loved them. [...] That is not so unlike us, is it?"
} 
Em Mulher-Maravilha, em contrapartida, há uma prioridade pela sutileza na persuasão familiar. Não há falas incisivas em tom de ordem para que a princesa desista do torneio: "[A vencedora] será nossa embaixadora para o mundo deles. Ela será uma amazona sem lar. Ela nunca poderá voltar a Themyscira. [...] Você ainda está se recuperando da sua enfermidade, Diana. Ninguém pensaria menos de você se não participasse" ", diz Hippolyta a Diana. Essa escolha pela não obviedade dá lugar a um jogo de não ditos que, não obstante, abala a relação entre mãe e filha, representada, além dos diálogos e das expressões faciais reveladoras, na estrutura das páginas seguintes:

Vemos que a primeira página, como o caso analisado na Figura 3, é simétrica em sua composição de quadros tanto vertical quanto horizontalmente. Essa característica mais uma vez dá a sensação de estabilidade das relações, pois apesar da expressão consternada de Diana, preocupada com o soldado sobrevivente, a calma de Hippolyta enquanto figura materna a ampara. Contudo, na página seguinte, a simetria é rompida. Isso se relaciona diretamente com a fala de Hippolyta, pois a rainha, conhecendo sua filha, sabe desde aquele momento da decisão que ela irá tomar e que suas habilidades a farão ganhar o torneio. Os três quadros centrais, como a esperança de Hippolyta, decrescem gradativamente, e o quadro central da página retrata o afastamento físico e o silêncio entre as duas logo antes de Diana romper com o olhar de sua mãe. Como na página, algo na ligação entre as duas é rompido.

\footnotetext{
8 "[The winner] will be our ambassador to their world. She will be na amazon without a home. She will never be able to return to Themyscira. [...] You are still recovering from your illness, Diana. No one would think less of you if you stood down."
} 
Figura 4: A persuasão de Hippolyta
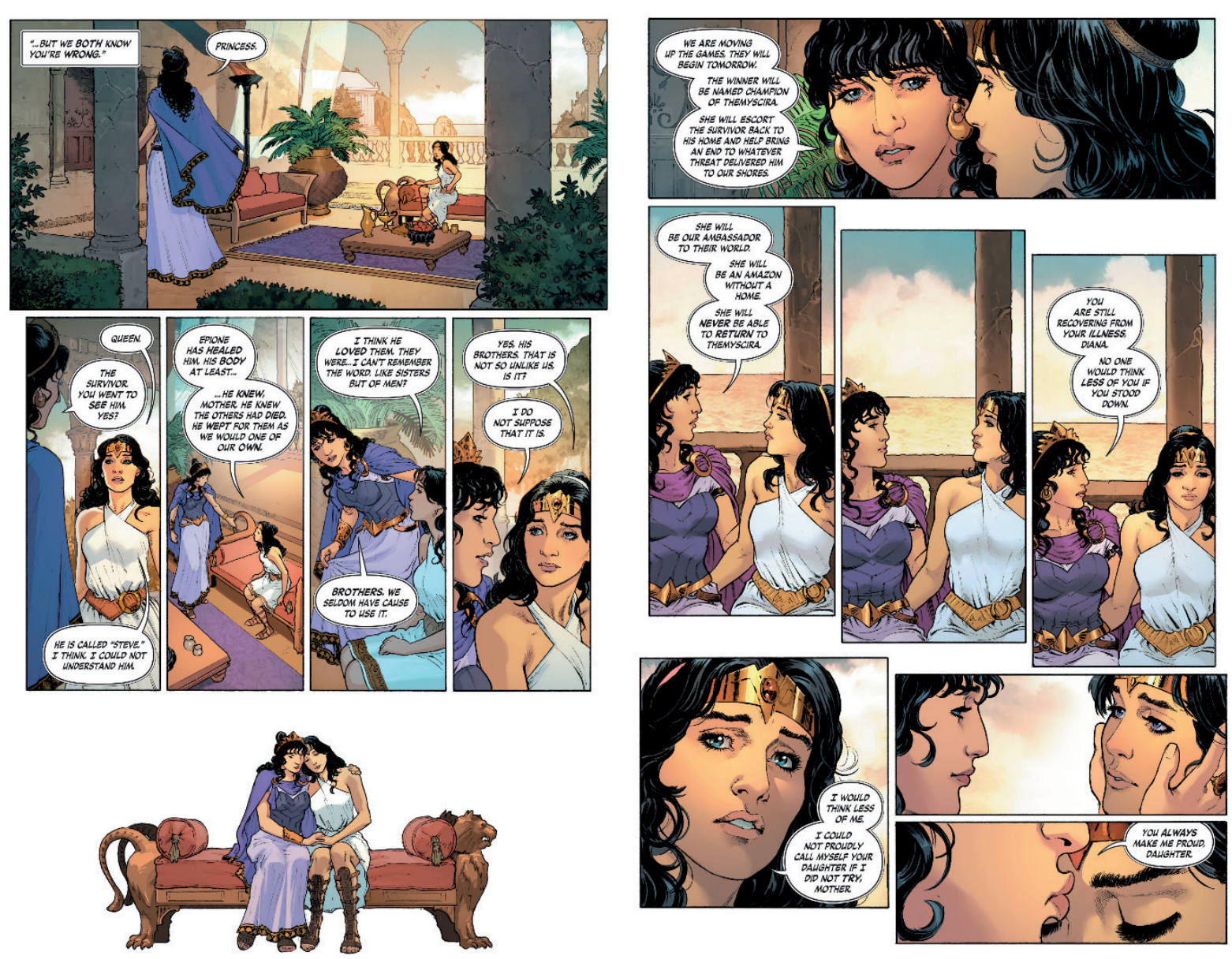

Fonte: RUCKA, G. et al. Wonder Woman: Year One. vol. 2. Burbank: DC Comics, 2017, n. p.

Também é significativo o posicionamento de mãe e filha ao longo das duas páginas. Karin Kukkonen (2013) mostra que ele está diretamente relacionado ao poder que cada personagem exerce na situação em questão. Apesar de o diálogo ter mais sutileza do que no conto, a hierarquia ainda é representada visualmente no posicionamento de Hippolyta sempre do lado esquerdo da página e, Diana, do lado direito: por influência da ordem de leitura ocidental da esquerda para a direita, sempre vemos Hippolyta antes de Diana. O único quadro em que esse molde não é seguido, também o único em que Diana aparece sozinha, é aquele em que ela dá o veredito à mãe de que, apesar de desencorajada, ela participará do torneio: se não participasse, diz, "Eu pensaria menos de mim."”

\footnotetext{
9 "I would think less of me."
} 
É um momento decisivo na HQ que a distingue do conto. Diana não faz nada às escuras, ao contrário da sereia, que procura a bruxa do mar e sela o pacto para obter as pernas na calada da noite. Essa distinção, é claro, diz respeito ao caráter elevado do super-herói, que, pela precisão de seu compasso moral, não tem nada a esconder. De qualquer forma, a transgressão da proibição, de forma mais ou menos explícita, é função importante da trajetória do herói dos contos identificada por Propp. É tendo a coragem de contestar a vontade alheia que as duas personagens tomam o passo decisivo na busca de sua realização existencial.

As três situações analisadas permitem observar que há semelhanças inegáveis entre o texto de Rucka e Scott em Wonder Woman: Year One e "A pequena sereia” de Andersen. Em alguns casos, elas aparecem de forma mais próxima, como na carência da protagonista em sair do ambiente familiar restrito e explorar um mundo humano desconhecido, que encapsula a empolgação que falta no lar. Ela se repete, ainda, no alerta por uma figura maternal (a mãe de Diana e a avó da sereia) de que tal busca resultará em consequências negativas, tentando dissuadir de forma muito semelhante as heroínas ao enaltecerem os benefícios que já possuem em ser quem são, amazona ou sereia. A manifestação tão semelhante de elementos-chave da morfologia de Propp em ambas as obras permite afirmar com alguma segurança que realmente existe uma relação hipertextual entre os textos, tendo a HQ adquirido algumas características do conto. Mesmo as discrepâncias encontradas no modo pelo qual a interação romântica é construída, menos imediata em Mulher-Maravilha, pode ser um indício da hipertextualidade, já que, como dito anteriormente, ela se dá também pelas transformações entre obras.

\section{CONSIDERAÇÕES FINAIS}

Ao longo de nossa análise, fizemos um breve passeio pelas veredas do maravilhoso enquanto grande gênero narrativo, buscando indícios de que é possível encontrar convergências entre contos de fadas e HQs de super-heróis apesar de sua considerável distância temporal na tradição artística da humanidade. Essas relações não se restringem à estrutura do gênero, havendo também algumas similaridades conceituais entre características do conto de fadas e da superaventura.

A análise proposta foi um vislumbre de que Mulher-Maravilha apresenta significativas convergências com narrativas maravilhosas, exemplificadas aqui por "A pequena sereia" numa relação de hipertextualidade. Comprovar essa raiz maravilhosa é um trabalho que evidentemente ainda necessita ser fortalecido, buscando outros contos 
de fadas que se façam presentes nesses quadrinhos. É também necessária a investigação de outros títulos de super-heróis, seja nas HQs ou em outras mídias, possibilitando novas discussões que revigorem ou refutem a continuidade da evolução do maravilhoso por esse gênero tão eclético, intertextual e contemporâneo.

Se a conexão entre maravilhoso e super-heroico ainda carece de grandiosos esforços, o que fica deste estudo é mais uma evidência de que universo da literatura e das artes está em constante diálogo consigo mesmo, sempre tendo no passado as matrizes necessárias para erigir-se com solidez no presente. 


\section{REFERÊNCIAS:}

ANDERSEN, H. C. A pequena sereia. In: MACHADO, A. M. (apresentação). Contos de Fadas: de Perrault, Grimm, Andersen \& outros. Trad. Maria Luiza X. de A. Borges. Rio de Janeiro: Zahar, 2010.

BAINBRIDGE, J. 'Worlds Withins Worlds': The Role of Superheroes in the Marvel and DC Universes. In: NDALIANIS, A (ed.). The contemporary comic book superhero. New York: Routledge, 2009, p. 64-85.

CHEVALIER, J. et al. Dicionário de símbolos: (mitos, sonhos, costumes, gestos, formas, figuras, cores, números). Trad. Vera da Costa e Silva et al. 20. ed. Rio de Janeiro: José Olympio, 2006.

COELHO, N. N. O conto de fadas. São Paulo: Ática, 1987.

ECO, U. Apocalípticos e integrados. Trad. Pérola de Carvalho. São Paulo: Perspectiva, 1979.

GOMES, J. P. F. Mulher-Maravilha pelas lentes do maravilhoso: uma análise proppiana de Year One. 2018. Monografia impressa (Mestrado em Letras) - Programa de PósGraduação em Letras, Universidade Estadual Paulista "Júlio de Mesquita Filho", São José do Rio Preto, 2018. Trabalho final da disciplina Vertentes e Expressões de Literatura Estrangeira: o conto maravilhoso nas literaturas de língua italiana, inglesa, francesa e espanhola.

GONGORA, A. P. S; MARTHA, A. A. P. Temas e imagens polêmicas nos contos de Hans Christian Andersen. In: CELLI - COLÓQUIO DE ESTUDOS LINGUÍSTICOS E LITERÁRIOS. 3, 2007, Maringá. Anais... Maringá, 2009, p. 118-128.

HEINBERG, A. Wonder Woman writer explains how The Little Mermaid influenced new film. [Entrevista cedida a] Nicole Sperling. Entertainment Weekly, maio 2017. Disponível em:<https://ew.com/movies/2017/05/19/wonder-woman-writer-little-mermaidinfluence/>. Acesso em 13 fev. 2019.

JENKINS, H. 'Just Men in Tights': Rewriting Silver Age Comics in an Era of Multiplicity. In: NDALIANIS, A (ed.). The contemporary comic book superhero. New York: Routledge, 2009, p. 16-43.

JOLlES, A. O conto. In: JOLlES, A. Formas Simples. São Paulo: Cultrix, 1976, p. 181204.

KUKKONEN, K. Studying comics and graphic novels. Malden: Wiley-Blackwell, 2013. 
LOEB, J.; MORRIS, T. Heróis e Super-heróis. In: IRWIN, W. (Coord.). Super-heróis e a filosofia: verdade, justiça e o caminho socrático. São Paulo: Madras, 2005, p. 23-31.

MARINHO, C. Poéticas do maravilhoso no cinema e na literatura. Belo Horizonte: PUC Minas: Autêntica, 2009.

MARINHO, C. Contribuições para uma poética do maravilhoso: um estudo comparativo entre a narratividade literária e cinematográfica. 2006. Tese (Doutorado em Estudos Comparados de Literaturas de Língua Portuguesa) - Faculdade de Filosofia, Letras e Ciências Humanas, Universidade de São Paulo, São Paulo, 2006. Acesso em: 17 fev. 2019.

NODELMAN, P. Words About Pictures: The Narrative Art of Children's Picture Books. Athens: University of Georgia Press, 1988.

PROPP, V. I. Morfologia do conto maravilhoso. Trad. Jasna Paravich Sarhan. 2.ed. Rio de Janeiro: Forense Universitária, 2010.

REBLIN, I. A. A superaventura: da narratividade e sua expressividade à sua potencialidade teológica. 2012. Tese (Doutorado em Teologia) - Escola Superior de Teologia, São Leopoldo, 2012.

REYNOLDS, R. Super heroes: a modern mythology. London: Batsford, 1992.

RUCKA, G. et al. Wonder Woman: Year One. vol. 2. Burbank: DC Comics, 2017.

SAMOYAUlT, T. A intertextualidade. Trad. Sandra Nitrini. São Paulo: Aderaldo \& Rothschild, 2008.

VOLOBUEF, K. Um estudo do conto de fadas. Revista de Letras, São Paulo (UNESP), v.3, 1993, p. 99-115.

WAID, M. et al. JLA. vol. 5. Burbank: DC Comics, 2014. 


\section{ANEXO - TRANSCRIÇÕES DOS BALÕES DE FALA}

Seguem abaixo as transcrições do conteúdo dos balões presentes nas figuras 2, 3 e 4, trechos de Wonder Woman: Year One. A decisão por colocá-los aqui deve-se ao fato de as dimensões reduzidas das imagens atrapalharem sua legibilidade, e de a quantidade de texto ser excessiva para as notas de rodapé. Apesar de esta não ser uma apresentação ideal como é originalmente na obra impressa, acredito que somente o acesso completo aos recursos pictóricos e verbais dos quadrinhos em conjunto com a estrutura das páginas possa fornecer uma leitura completa dessa forma de arte.

Legenda para leitura das transcrições:

PERSONAGEM: texto em balão de fala.

PERSONAGEM: [texto em recordatório].

Linha em branco - mudança de quadros.

[...] - quadro em que não há texto em balão de fala ou recordatório.

*** - mudança de página (apenas para casos de página simples. Em páginas duplas, feitas para serem lidas como um todo, não há essa divisão).

Figura 2 - A carência de Diana

ARETO: ... just look up!

DIANA: I've seen them before.

ARETO: And so you've learned all there is to learn? The heavens have revealed their mysteries to you, have they?

DIANA: You know that is not what I'm saying, Areto.

ARETO: What I know is that every time you join us in our observations, you refuse to turn your eye up...

ARETO: ...but instead insist upon casting your gaze out, Diana. And I don't understand why.

DIANA: But you do, sister.

DIANA: You do, even if you don't feel it.

KASIA: You vex Areto on purpose, Diana.

DIANA: I don't, Kasia, you know I don't.

KASIA: No, I know.

DIANA: I can see the beauty of the skies, I can see the poetry in their motion. But all we do is bear witness. 
DIANA: All of you remember before, Kasia. You can recall the world you left, even if the memories of it bring you pain. I've never seen what lies beyond our shores.

DIANA: Do you really wonder why my eye goes to the horizon instead of the skies? (RUCKA et al., 2017, n.p.).

Tradução nossa:

ARETO: ... só olhe para cima!

DIANA: Eu já as vi antes.

ARETO: E então você já aprendeu tudo que há para se aprender? Os céus revelaram seus mistérios para você?

DIANA: Você sabe que não é isso que estou dizendo, Areto.

ARETO: O que eu sei é que toda vez que você se une a nós nas observações, você se recusa a voltar seu olhar para cima...

ARETO: ... mas, em vez disso, insiste em olhar para o horizonte, Diana. E eu não entendo o porquê.

DIANA: Mas você entende, irmã.

DIANA: Você entende, mesmo que não sinta o mesmo.

KASIA: Você provoca Areto de propósito, Diana.

DIANA: Não, Kasia. Você sabe que não.

KASIA: Não, eu sei.

DIANA: Posso ver a beleza dos céus, posso ver a poesia de seu movimento. Mas tudo que fazemos é meramente testemunhar.

DIANA: Todas vocês lembram de antes, Kasia. Vocês se recordam no mundo que deixaram, mesmo que as memórias dele lhes tragam dor. Eu nunca vi o que há além-mar.

DIANA: Você realmente se pergunta por que meus olhos se voltam para o horizonte em vez dos céus?

Figura 3 - Distanciamento da família e aproximação com o humano

IO: --says to the Oracle...

SOFIA: ... "but you knew that already!"

AMAZONA NÃ̃ NOMEADA: Ha!

DIANA: That joke is as old as you are, Io-- 
JOVEM NÃO NOMEADA: --to even drink?

STEVE: Freshly minted and legal.

JOVEM NÃO NOMEADA: So it's your birthday? Did you get a cake? Did you make a wish?

SOFIA: You got lucky.

DIANA: Apparently, I get Lucky a lot, Sofia.

IO: Wish you two would just hold still for a second!

NICK: This is going to suck.

STEVE: Five-and-a-half miles with fins, Nick. Daki can do this in his sleep.

DAKI: Well... maybe while napping.

IO: She emerges like Aphrodite. Gods, she's killing me.

SOFIA: I thought she and Kasia...?

IO: ... and Meghara and Evrayle. I don't even know...

PADRE: You may kiss the bride.

SACERDOTISA: ...our patrons of Olympus who sustain us, protect us, and nurture us. We who are your daughters, chosen and honored, bound in our duty. We return that which is given, gracious for all that is bestowed...

MAYA: ...I'm not looking forward to that day.

NICK: It's what we've trained for, Maya. after all!

PHILIPPUS: ...wish we had more horses for the games this year. We're amazons,

[...] (RUCKA et al., 2017, n.p.).

Tradução nossa:

IO: --diz ao Oráculo...

SOFIA: ... "mas você já sabia disso!"

AMAZONA NÃO NOMEADA: Ha!

DIANA: Essa piada é tão velha quanto você, Io--

JOVEM NÃO NOMEADA: --para sequer beber?

STEVE: A partir de hoje, sim.

JOVEM NÃO NOMEADA: Então é seu aniversário? Você ganhou um bolo? Você fez um pedido? 
SOFIA: Você teve sorte.

DIANA: Aparentemente tenho sorte sempre, Sofia.

IO: Queria que vocês duas sossegassem por um segundo!

NICK: Isso vai ser um saco. dormindo.

STEVE: Quase nove quilômetros com pé-de-pato, Nick. Daki consegue fazer isso

DAKI: Bem... talvez cochilando.

IO: Ela emerge como Afrodite. Deuses, ela está me matando.

SOFIA: Achei que ela e Kasia...?

IO: ...e Meghara e Evrayle. Eu já nem sei mais...

PADRE: Você pode beijar a noiva.

SACERDOTISA: ... nossos patronos do Olimpo, que nos sustentam, protegem e nutrem. Nós, que somos suas filhas, escolhidas e honradas, unidas pelo nosso dever. Nós devolvemos aquilo que é dado, gratas por tudo que é concedido...

MAYA: ...Não estou ansiosa para esse dia.

NICK: É para isso que treinamos, Maya.

PHILIPPUS: ...queria que tivéssemos mais cavalos para os jogos deste ano. Afinal de contas, somos amazonas!

Figura 4 - A persuasão de Hippolyta

HIPPOLYTA: [...but we both know you're wrong.]

HIPPOLYTA: Princess.

DIANA: Queen

HIPPOLYTA: The survivor. You went to see him, yes?

DIANA: He is called "Steve". I think I could not understand him.

DIANA: Epione has healed him. His body at least... He knew, mother, he knew the others had died. He wept for them as we would one of our own.

DIANA: I think he loved them. They were... I can't remember the word. Like sisters, but of men?

HIPPOLYTA: Brothers. We seldom have cause to use it.

DIANA: Yes, his Brothers. That is not so unlike us, is it?

HIPPOLYTA: I do not suppose that it is.

\section{$[\ldots]$}


Tradução nossa:

HIPPOLYTA: [...mas ambas sabemos que você está errada.]

HIPPOLYTA: Princesa.

DIANA: Rainha.

HIPPOLYTA: O sobrevivente. Você foi vê-lo, sim?

DIANA: Seu nome é "Steve". Eu acho que não pude compreendê-lo.

DIANA: Epione o curou. Seu corpo, ao menos... Ele sabia, mãe, ele sabia que os outros tinham morrido. Ele chorou pore les como nós choraríamos por uma das nossas.

DIANA: Eu acho que ele os amava. Eles eram... Não me lembro da palavra. Como irmãs, mas para homens?

HIPPOLYTA: Irmãos. Raramente temos razão para usá-la.

DIANA: Sim, seus irmãos. Isso não é tão diferente de nós, é?

HIPPOLYTA: E não acho que seja.

$* * *$

HIPPOLYTA: We are moving up the games, they will begin tomorrow. The winner will be named champion of Themyscira. She will escort the survivor back to his home and help bring an end to whatever threat delivered him to our shores.

HIPPOLYTA: She will be our ambassador to their world. She will be na amazon without a home. She will never be able to return to Themyscira.

\section{$[\ldots]$}

HIPPOLYTA: You are still recovering from your illness, Diana. No one would think less of you if you stood down.

DIANA: I would think less of me. I could not proudly call myself your daughter if I did not try, mother.

\section{$[\ldots]$}

HIPPOLYTA: You always make me proud, daughter. 


\section{Tradução nossa:}

HIPPOLYTA: Estamos adiantando os jogos, eles começarão amanhã. A campeã será nomeada campeã de Themyscira. Ela irá escoltar o sobrevivente de volta para sua terra e ajudar a encerrar qualquer que seja a ameaça que o trouxe até nossas praias.

HIPPOLYTA: Ela será nossa embaixadora para o mundo deles. Ela será uma amazona sem lar. Ela nunca mais poderá voltar a Themyscira.

\section{$[\ldots]$}

HIPPOLYTA: Você ainda está se recuperando de sua enfermidade, Diana. Ninguém pensaria menos de você se não participasse.

DIANA: Eu pensaria menos de mim. Eu não seria digna de me chamar de sua filha se eu não tentasse, mãe. [...]

HIPPOLYTA: Você sempre me deixa orgulhosa, filha. (RUCKA et al., 2017, n.p.). 